\section{International Scientific Journal Theoretical \& Applied Science}

p-ISSN: 2308-4944 (print) e-ISSN: 2409-0085 (online)

Year: 2018 Issue: $06 \quad$ Volume: 62

Published: $30.06 .2018 \quad$ http://T-Science.org

SECTION 9. Chemistry and chemical technology.
G.I. Kelbaliev Institute of Catalyses and Inorganic Chemistry, NAS of Azerbaijan

T.Sh. Hasanova Sumgait State University, Azerbaijan Republic

M.M. Samedov Sumgait State University, Azerbaijan Republic

\title{
INVESTIGATION OF GRANULATION PROCESS AND INFLUENCE OF INTENSIFYING ADDITIONS ON STRENGTH OF SUPERPHOSPHATE GRANULES
}

Abstract: The possibilities of improvement of the qualitative indices of superphosphate fertilizers with use of intensifying additions boron $\left(\mathrm{B}_{2} \mathrm{O}_{3}\right)$ and calcium $(\mathrm{CaO})$ oxides with ammonium hydroxide $\left(\mathrm{NH}_{4} \mathrm{OH}\right)$ favoring decrease of porosity and increase of granules strength are considered. The mass-exchange problem of moistening of granules has been solved, the dependence of thickness of moistening and strength on granule porosity has been determined.

Key words: superphosphate, granulation, moistening, diffusion, porosity, strength.

Language: English

Citation: Kelbaliev GI, Hasanova TS, Samedov MM (2018) INVESTIGATION OF GRANULATION PROCESS AND INFLUENCE OF INTENSIFYING ADDITIONS ON STRENGTH OF SUPERPHOSPHATE GRANULES. ISJ Theoretical \& Applied Science, 06 (62): 250-257.

Soi: http://s-0-i.org/1.1/TAS-06-62-44 Doi: crossef https://dx.doi.org/10.15863/TAS.2018.06.62.44

\section{Introduction}

Granulation processes of powdery materials find a wide application in various areas of chemical, food, pharmaceutical and metallurgical industry. The important properties of the prepared granules are physical-chemical (size, density, porosity, thermal stability) and rheological properties (fluidity, strength, hardness, blocking). The blocking of granules has been connected with their consolidation in a layer under action of own weight and is determined by a character and moisture absorption capacity from environment at cooling, storage and transportation of mineral fertilizers [1,2]. In this connection, at an estimation of physical-mechanical properties of granules of fertilizer it is important to take into account a moisture absorption at cooling and storage, connected with hygroscopicity of a material of a granule and one can consider as one of the estimated characteristics of quality. It should be noted that as a result of moisture absorption from environment only an insignificant part of nearsurface layer is moistened (to $5-10 \%$ ) which leads to a strength loss, connected with formation of a surface loose structure and favoring to destruction and form deformation, and also to blocking, i.e. to adherence of granules and formations of lumps under action of weight of overlying layers. With the aim of an exception of these phenomena it is necessary to decrease a degree of moisture at the expense of porosity which is reached by use of various mineral additives or surface-active substances [3-8].

It should be noted that these phenomena essentially influence on granule strength a value of which, except other parameters, depends on granule porosity. This dependence is expressed by various formulae presented in works $[4,5]$.

$$
\frac{d \ln \left(\Delta-\Delta_{0}\right)}{d C_{d}}=k_{0} \frac{\Delta}{C_{d}^{2}}
$$

In works [9-11] the empirical equations for determination of granules strength are presented.

$$
\begin{aligned}
\Delta & =\Delta_{0} \exp (-b \varepsilon), \quad[9] \\
\Delta & =\frac{1-\varepsilon}{\varepsilon} \frac{F}{a^{2}}, \quad[10] \\
\Delta & =3.7(1-\varepsilon)^{4} \frac{F}{a^{3 / 2} m^{1 / 2}}
\end{aligned}
$$

here $F$ - average strength per unit of area of crosssection, $m$ - characteristic dimension. The reduced dependences (2)- (4) show that with decrease of porosity a granules strength is increased. 


\begin{tabular}{|c|c|c|c|c|c|c|}
\hline Impact Factor: & $\begin{array}{l}\text { ISRA (India) } \\
\text { ISI (Dubai, UAE } \\
\text { GIF (Australia) } \\
\text { JIF }\end{array}$ & $\begin{array}{r}=1.344 \\
=0.829 \\
=0.564 \\
=1.500\end{array}$ & $\begin{array}{l}\text { SIS (USA) } \\
\text { PИHЦ (Russia) } \\
\text { ESJI (KZ) } \\
\text { SJIF (Morocco) }\end{array}$ & $\begin{array}{l}=0.912 \\
=0.207 \\
=4.102 \\
=\mathbf{2 . 0 3 1}\end{array}$ & $\begin{array}{l}\text { ICV (Poland) } \\
\text { PIF (India) } \\
\text { IBI (India) }\end{array}$ & $\begin{array}{l}=6.630 \\
=1.940 \\
=4.260\end{array}$ \\
\hline
\end{tabular}

The purpose of this investigation is the improvement of qualitative and quantitative indices by use of various additions (boron oxide $\left(\mathrm{B}_{2} \mathrm{O}_{3}\right)$ and calcium oxide $(\mathrm{CaO})$ with ammonium hydroxide $\left(\mathrm{NH}_{4} \mathrm{OH}\right)$ for decrease of their porosity and increase of strength and also enrichment of superphosphate granules by additional elements (nitrogen, manganese).

\section{Model of natural moistening of granules}

At cooling, transportation and storage of superphosphate granules a natural moistening takes place, and a moisture penetration depth depends on a granule structure porosity, moisture content in air, a size of granules, etc. The natural moistening of porous structure is the mass-exchange process and at low values of Peclet $\mathrm{Pe}=V R / D^{<<1}$ and Fourier numbers $F o=D_{0} t / R^{2}<<1$ for spherical granule is described by an equation of a view

$$
\begin{gathered}
\frac{\partial C}{\partial t}=\frac{D_{*}}{r^{2}} \frac{\partial}{\partial r}\left(r^{2} \frac{\partial C}{\partial r}\right) \\
r=R, t>0, \quad C=C_{S} ; \quad t=0, \quad C=C_{0} ; \\
r \rightarrow \infty, \quad C=C_{0}
\end{gathered}
$$

where $C, C_{0}, C_{S}-$ current concentration and moisture concentration on granule surface and in flow capacity. Using a set of experimental investigations according to the determination of effective diffusion coefficient in porous media [12], one can prepare empirical dependence of a view [13]

$\frac{D_{*}}{D_{0}}=0.62 \varepsilon+0.28 \varepsilon^{4.4}$

At $\varepsilon<0.55$ an expression (6) taking into account pore tortuosity $\eta_{d}$ passes into linear dependence (fig.1) of a view.

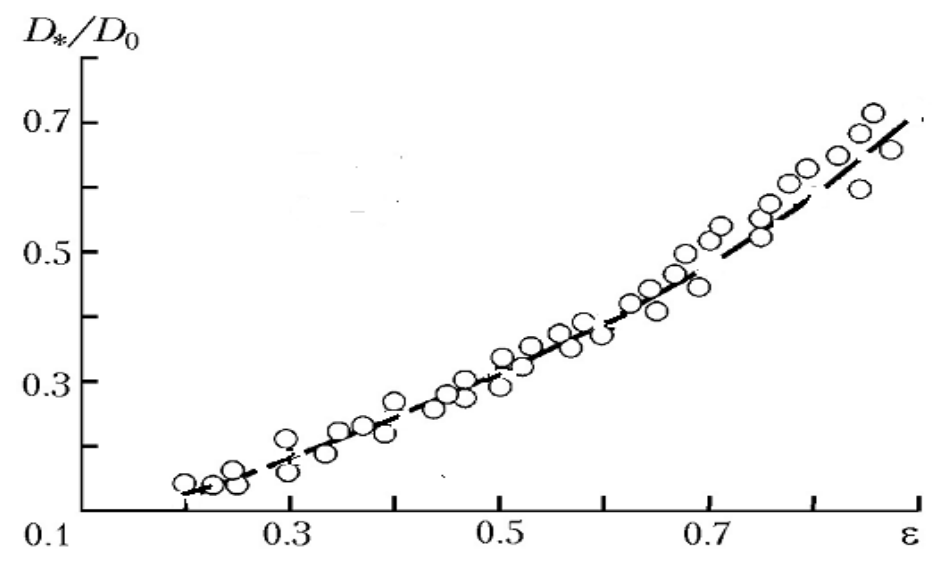

Fig.1. Change of effective diffusion coefficient depending on porosity (points - experimental data [12]).

$$
\frac{D_{*}}{D_{0}} \approx 0.62 \varepsilon \eta_{d}
$$

A solution of equation (5) at given boundary conditions and insignificant values of Fourier number can be prepared as

$$
\frac{C(r, t)-C_{S}}{C_{0}-C_{S}}=\operatorname{erf}\left(\frac{R-r}{2 \sqrt{D_{0} t \varepsilon \eta_{d}}}\right)
$$

here $\operatorname{erf}(x)=\frac{2}{\sqrt{\pi}} \int_{0}^{\infty} e^{-x^{2}} d x-$ error integral, a value of which is changed within the ranges from 0 to 1 at $x \rightarrow \infty$. Full quantity of a moisture, transferred in time $t_{S}$ we'll define as

$$
J=-\left.\int_{0}^{t_{S}} D_{*} \frac{\partial C}{\partial r}\right|_{r=R} d t=2\left(C_{S}-C_{0}\right)\left(\frac{t_{S} D_{*}}{\pi}\right)^{1 / 2}
$$

From this equation, having lowered the elementary transformations, we'll define average transfer rate as $J_{S}=J / t_{S}$ and comparing with general mass transfer through surface unit $J_{S}=K\left(C_{S}-C_{0}\right)$, we'll define mass-transfer coefficient as

$$
K=2\left(\frac{D_{*}}{\pi t_{S}}\right)^{1 / 2} \approx \frac{D_{*}}{\delta}
$$




\begin{tabular}{l|lr|ll|ll} 
& ISRA (India) & $=\mathbf{1 . 3 4 4}$ & SIS (USA) & $=\mathbf{0 . 9 1 2}$ & ICV (Poland) & $=\mathbf{6 . 6 3 0}$ \\
Impact Factor: & ISI (Dubai, UAE) $=\mathbf{0 . 8 2 9}$ & PUHЦ (Russia) $=\mathbf{0 . 2 0 7}$ & PIF (India) & $=\mathbf{1 . 9 4 0}$ \\
& GIF (Australia) & $\mathbf{0 . 5 6 4}$ & ESJI (KZ) & $=4.102$ & IBI (India) & $=\mathbf{4 . 2 6 0}$ \\
& JIF & $=\mathbf{1 . 5 0 0}$ & SJIF (Morocco) & $=\mathbf{2 . 0 3 1}$ & & \\
\hline
\end{tabular}

here $\delta$ - moisture penetration depth, which we'll define from (10) taking into account (7) as

$$
\delta \approx 2\left(\pi t_{s} D_{*}\right)^{1 / 2}=2.8\left(D_{0} t_{S} \varepsilon \eta_{d}\right)^{1 / 2}
$$

The equation (11) can be transformed to a view

$$
\frac{\delta}{R} \approx 2.8 \mathrm{Fo}^{1 / 2}\left(\varepsilon \eta_{d}\right)^{1 / 2}
$$

where $F_{O}=D_{0} t_{S} / R^{2}-$ Fourier number. As follows from the equation (12), a moisture thickness depends on medium porosity, the more porosity, the more deeply a moisture penetrates into granule volume $\sim \varepsilon^{1 / 2}$. Based on the equation (12) and condition $j=\left.D_{*} \frac{\partial C}{\partial r}\right|_{r=R}$, we'll define an expression for Sherwood number as

$$
\mathrm{Sh}=\frac{2}{\sqrt{\pi \varepsilon \eta_{d}}} \mathrm{Fo}^{-1 / 2}
$$

The numerous experimental and practical results [13-15] showed that the molecular diffusion coefficient of a moisture in porous media is fluctuated within the ranges of $D \approx 10^{-9}-10^{-12} \mathrm{M}^{2} / \mathrm{C}$. Under the conditions that $R=2 \times 10^{-3} \mathcal{M}, \varepsilon=0,3-0,5$, one can estimate a number $\mathrm{Fo}=0.01-0.03$ and layer thickness of a granule moistening equal to $\delta / R \approx 0.1-0.3$.

Thus, as a result of moistening, a granule surface becomes friable and loses strength, which leads to a deformation, to surface deterioration and adherence of granules. First of all, such state has been connected with moisture effective diffusion depending on porosity of structure. Naturally, to decrease granules strength loss at storage and for providing of constant strength it is necessary to prepare granules with the consolidated structure or to use defined additions to binding agent which as a result of crystallization at their drying, favor a strengthening of bonds between particles of a powder and, hammering in pores, decrease a granule free volume. As follows from the equations (2) - (4), by decrease of porosity or degree of moistening an increase of strength and yield of qualitative granules can be reached.

\section{Experimental investigation of influence of additions on granules strength}

A choice of the corresponding addition in the form of organic or inorganic compounds should be carried out on the basis of the following reasons: a) used compound should be completely dissolved in binding agent (in water); b) its crystallization in drying process should provide a formation of the additional «bridges» between particles of powder and decrease of free volume in granule; B) to improve qualitative and quantitative indices of the marketable products. On this basis, the influence of mixture of boron $\left(\mathrm{B}_{2} \mathrm{O}_{3}\right)$ and calcium $(\mathrm{CaO})$ oxides with ammonium hydroxide $\left(\mathrm{NH}_{4} \mathrm{OH}\right)$ on composition and physical-chemical properties of the granulated superphosphate has been investigated under laboratory conditions. The experimental investigations were carried out in laboratory drum granulator with diameter $12 \mathrm{~cm}$, length $80 \mathrm{~cm}$, angular rotation rate $30 \mathrm{~min}^{-1}$ and degree of filling equal to $15 \%$ (fig. 2 ). 


\begin{tabular}{l|lr|ll|ll} 
& ISRA (India) & $=\mathbf{1 . 3 4 4}$ & SIS (USA) & $=\mathbf{0 . 9 1 2}$ & ICV (Poland) & $=\mathbf{6 . 6 3 0}$ \\
Impact Factor: & ISI (Dubai, UAE) $=\mathbf{0 . 8 2 9}$ & PUHL (Russia) $=\mathbf{0 . 2 0 7}$ & PIF (India) & $=\mathbf{1 . 9 4 0}$ \\
& GIF (Australia) & $\mathbf{0 . 5 6 4}$ & ESJI (KZ) & $=\mathbf{4 . 1 0 2}$ & IBI (India) & $\mathbf{4 . 2 6 0}$ \\
& JIF & $=1.500$ & SJIF (Morocco) & $=\mathbf{2 . 0 3 1}$ & & \\
\hline
\end{tabular}

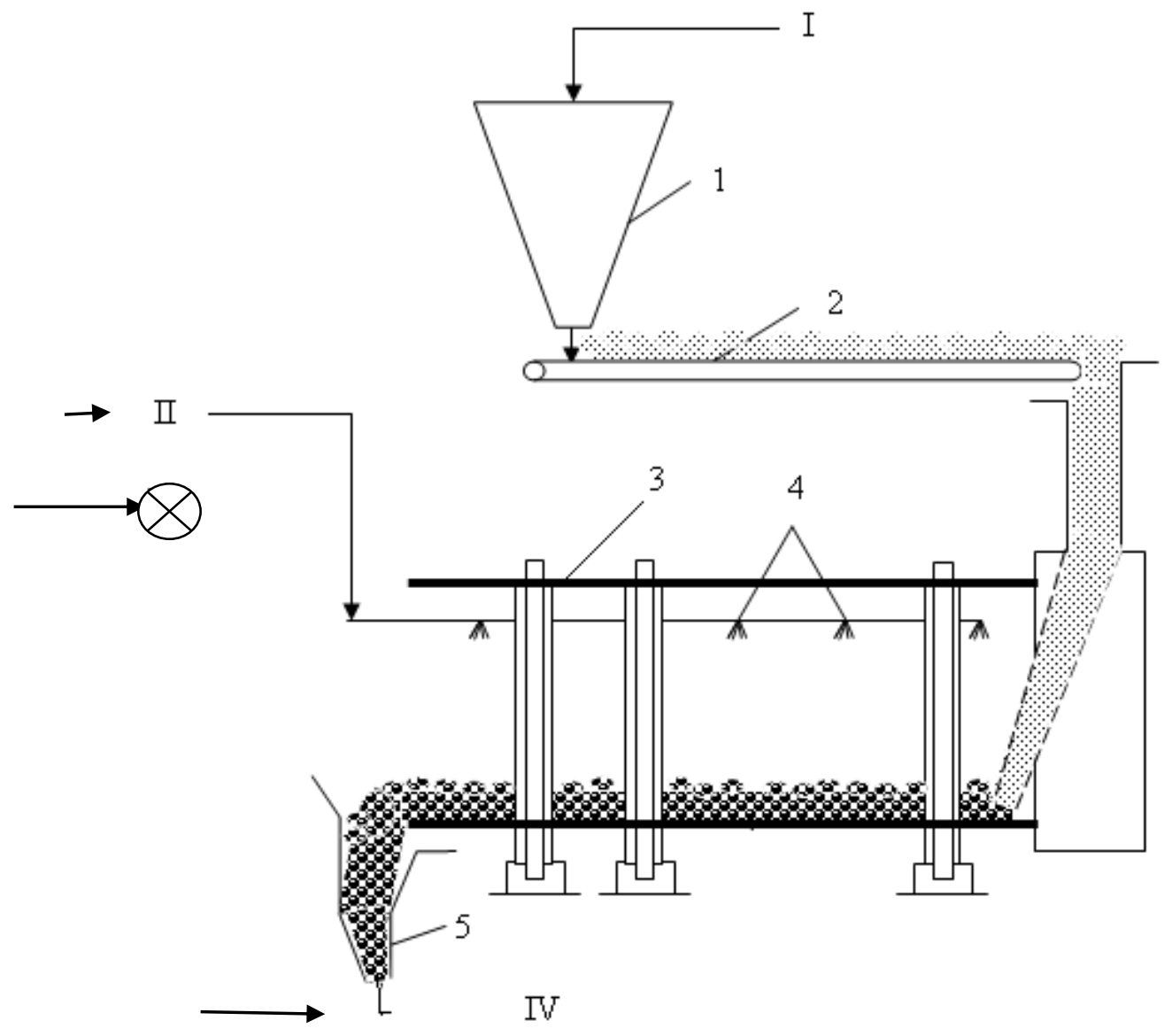

Fig.2. Scheme of laboratory facility of granulation of powdered materials in drum apparatuses: 1 - bunker for particulate powders; 2 - transporter; 3- rotating drum apparatus; 4- jets; 5-bunker; I- powder feed line; II- feed of binding substance; III- additions feed; IV- moisture granules in drying apparatus.

To the drum apparatus for moistening of powdered superphosphate by means of the nozzles located in several points longwise, the binding agent with composition: $\mathrm{B}_{2} \mathrm{O}_{3}-18-20 \%, \mathrm{NH}_{4} \mathrm{OH}-6-8 \%$,
$\mathrm{CaO}-4-5 \%$, water $-67-72 \%$ was given. The results of experimental investigations are presented below in Table 1.

Table 1.

Dependence of physical-chemical indices and composition of the finished product ( $\%$ mass) on quantity and composition of addition $\left(\mathrm{B}_{2} \mathrm{O}_{3}-18-20 \%, \mathrm{NH}_{4} \mathrm{OH}-6-8 \%, \mathrm{CaO}-4-5 \%, \mathrm{H}_{2} \mathrm{O}-67-72 \%\right)$.

\begin{tabular}{|l|l|l|l|l|l|l|l|}
\hline $\begin{array}{c}\text { Ratio of } \\
\text { superphosphate and } \\
\text { binding liquid }\end{array}$ & $\begin{array}{c}\mathrm{P}_{2} \mathrm{O}_{5} \\
\text { (adopt.) }\end{array}$ & $\begin{array}{c}\mathrm{P}_{2} \mathrm{O}_{5} \\
\text { (free) }\end{array}$ & $\mathrm{N}$ & $\mathrm{B}$ & $\mathrm{H}_{2} \mathrm{O}$ & $\Delta, \mathrm{MPa}$ & $\begin{array}{c}\text { Yield, } \\
Q, \%\end{array}$ \\
\hline $1: 0.10$ & 19.43 & 3.27 & 0.21 & 0.42 & 1.60 & 18.4 & 72.0 \\
$1: 0.15$ & 19.40 & 2.92 & 0.30 & 0.58 & 1.82 & 20.9 & 78.3 \\
$1: 0.20$ & 19.35 & 2.80 & 0.42 & 0.63 & 2.01 & 24.1 & 81.7 \\
$1: 0.30$ & 19.30 & 2.26 & 0.55 & 0.80 & 2.11 & 25.2 & 86.7 \\
$1: 0.35$ & 19.28 & 2.20 & 0.70 & 0.93 & 2.19 & 26.0 & 85.8 \\
$1: 0.40$ & 19.07 & 2.18 & 0.89 & 1.12 & 2.35 & 23.3 & 68.4 \\
$1: 0.45$ & 18.82 & 2.15 & 1.20 & 1.39 & 2.60 & 21.1 & 62.5 \\
$1: 0.50$ & 18.34 & 2.12 & 1.31 & 1.50 & 2.89 & 19.2 & 59.2 \\
\hline
\end{tabular}


As follows from this table the most high strength of granules is reached at ratio of powdered superphosphate and binding agent (addition) at value of 1: $(0,25-0,35)$. The limestone consumption is completely excluded, and an acidic superphosphate is neutralized by ammonia water constituent of moistening liquid. An increase of granules strength is explained by that $\mathrm{B}_{2} \mathrm{O}_{3}$ and $\mathrm{CaO}$ constituent of binding agent more strongly bind superphosphate particles at formation of granules, fill the pores and provides their fuller balling. Ammonia water constituent of moistening liquid reacts with free phosphoric acid; monoammonium phosphate constituent of powdered superphosphate and prepared in this case is crystallized. The forming crystalline structure of monoammonium phosphate is accompanied with formation of point defects, which favorably influence on the mechanism of formation of granules. Thus, the carrying out of the process in this interval of ratios of powdered superphosphate and moistening liquid allows to increase the granules strength to 25-26 MPa and to improve the qualitative characteristics of the end product due to its enrichment by such nourishing elements as nitrogen and manganese.

\section{Discussion and analysis of results}

The mechanism of improvement of the qualitative indices of superphosphate fertilizers consists in addition of various components of mixture of boron $\left(\mathrm{B}_{2} \mathrm{O}_{3}\right)$ and calcium $(\mathrm{CaO})$ oxides with ammonium hydroxide $\left(\mathrm{NH}_{4} \mathrm{OH}\right)$ to binding agent at formation of granules, which favors increase of granules strength in decrease of their porosity. The model of natural moistening of granules has been proposed; as a result of which the moistening thickness depending on porosity and Fo number has been estimated (12). Using experimental data [9-11], we'll dependence of granules strength on porosity as

$$
\Delta=\left(0,008+9,6 \varepsilon^{5}\right)^{-1}
$$

with correlation coefficient equal to $r^{2} \approx 0.9421$ (fig.3), i.e. with increase of granules porosity the strength is essentially decreased.

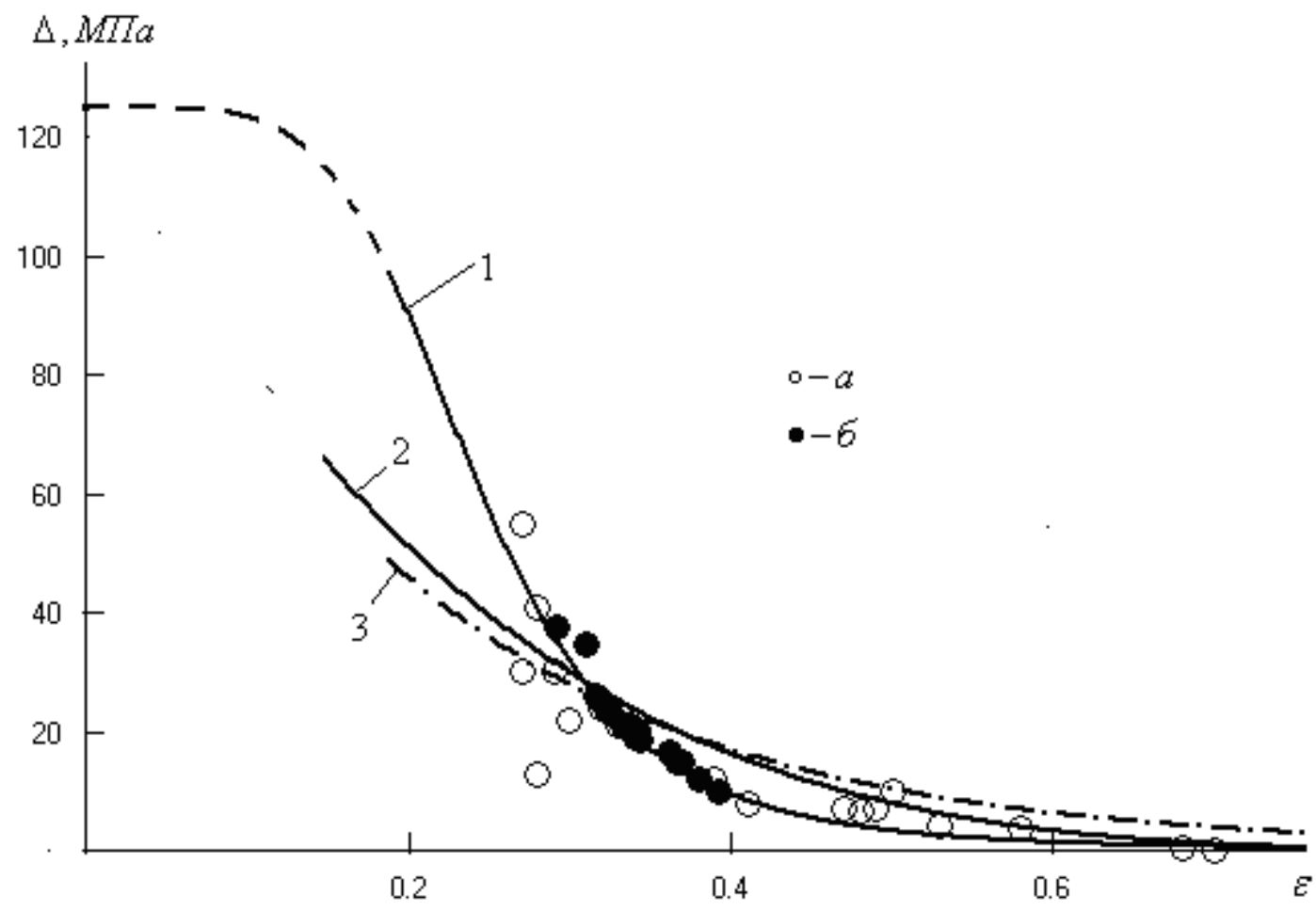

Fig. 3. Dependence of granules strength on porosity: 1- calculation on formula (11); 2- calculation on formula (4); 3- calculation on formula (2); a- experimental data of works [9-11]; b- experimental investigations of this work.

As follows from fig.3, the proposed equation (14) more precisely describes experimental values of strength than the expressions (2) and (4). In the same figure the results of investigations prepared experimentally for superphosphate fertilizers are presented.

Based on results of Table 1 one can prepare a dependence between porosity and concentration of the binding agent as 


\begin{tabular}{l|lr|ll|ll} 
& ISRA (India) & $=\mathbf{1 . 3 4 4}$ & SIS (USA) & $=\mathbf{0 . 9 1 2}$ & ICV (Poland) & $=\mathbf{6 . 6 3 0}$ \\
Impact Factor: & ISI (Dubai, UAE) $=\mathbf{0 . 8 2 9}$ & PUHЦ (Russia) $=\mathbf{0 . 2 0 7}$ & PIF (India) & $=\mathbf{1 . 9 4 0}$ \\
& GIF (Australia) & $\mathbf{0 . 5 6 4}$ & ESJI (KZ) & $=4.102$ & IBI (India) & $=\mathbf{4 . 2 6 0}$ \\
& JIF & $=\mathbf{1 . 5 0 0}$ & SJIF (Morocco) & $=\mathbf{2 . 0 3 1}$ & & \\
\hline
\end{tabular}

$$
\begin{aligned}
\varepsilon & =0,38-0,4 C_{d}+0.64 C_{d}^{2} \\
\Delta & =9.5+104.3 C_{d}-168.3 C_{d}^{2}
\end{aligned}
$$

with correlation coefficient equal to $r^{2}=0.9525$. Here $C_{d}-$ total quantity of impurity (in mass parts).

A yield of the marketable qualitative product (granules with sizes 1-4 mm) and with high degree of strength can be determined on formula

$$
Q=Q_{0}+f\left(\Delta, C_{d}\right)
$$

where $Q_{0}=\frac{\pi \rho_{g}}{2} \int_{a_{0}}^{a_{m}} P(a) a^{2} d a-$ quantity of the worked out granules with sizes $a_{0} \leq a \leq a_{m}$ $\left(a_{0}=1 \mathrm{~mm}, a_{M}=4 \mathrm{MM}\right)$ without use of various additions, $P(a, t)$ - granule distribution function on sizes and on time. In work [16] the function $P(a, t)$, characterizing evolution of granule distribution function in drum apparatus is determined on the basis of solution of Fokker-Plank equation and with use of the experimental investigations a practical value is restored. The function $f\left(\Delta, C_{d}\right)$ determines an influence of strength and concentration of additions on total productivity of the apparatus and this expression can be prepared in empirical form on the basis of the experimental investigations. In particular, in works $[4,5]$ this expression is non-linear function of a view $f\left(\Delta, C_{d}\right)=k \Delta^{n}$. However the preparation of any deterministic description of yield dependence on concentration of additions or on strength presents large difficulties. Based on results of Table 1 a yield of the marketable fraction can be approximated as

$$
Q=37.2+441.0 C_{d}-1162.1 C_{d}^{2}+715.6 C_{d}^{3}
$$

As follows from Table 1 at low ratios of powdered superphosphate and moistening liquid 1: $(0,1-0,2)$ a use of addition becomes unreasonable, as far as a content of free $\mathrm{P}_{2} \mathrm{O}_{5}$ is increased, as ammonia water constituent of moistening liquid becomes insufficient for neutralization of free phosphoric acid and a quantity of $\mathrm{B}_{2} \mathrm{O}_{3}$ and $\mathrm{CaO}$ doesn't provide sufficient consolidation of granules. At higher ratios of powdered superphosphate and moistening liquid 1: $(0,40-0,50)$ the granule formation is deteriorated and a yield of the marketable product falls essentially (fig.4).

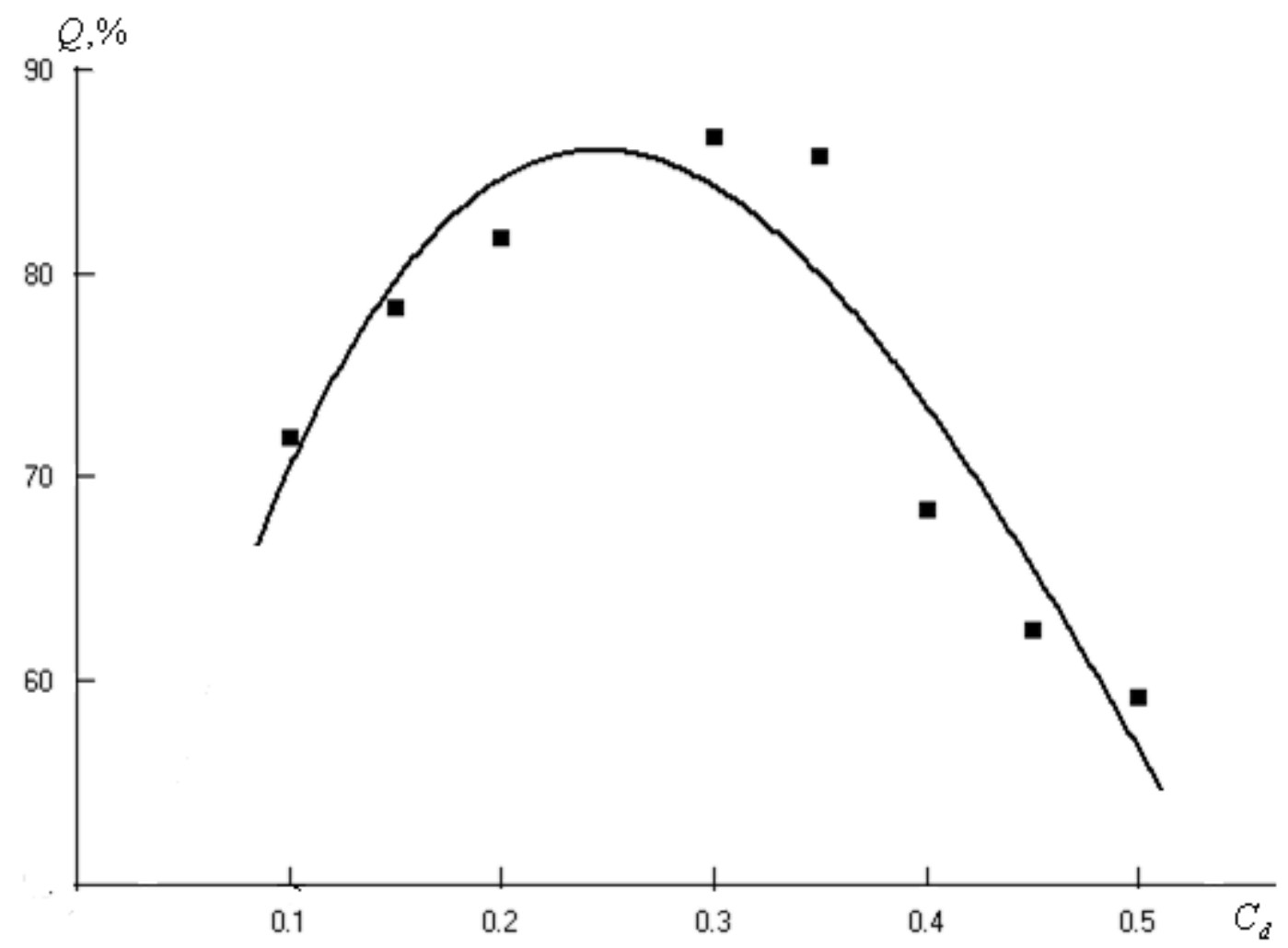

Fig.4. Dependence of yield of the marketable products on additions concentration

A yield of the marketable product passes through maximum and a maximum is reached at ratios of powdered superphosphate and moistening liquid equal to 1: (0.30-0.35), which is the most optimal condition for carrying out of the process with use of the various additions. In these conditions the 
higher yield of the marketable product, having high strength and correspondingly, low porosity providing small moisture capacity is reached.

\section{Conclusions}

It has been established by study of ways of intensification of granulation process of powdery superphosphate with application of binding reagent suspension of boron oxide $\left(\mathrm{B}_{2} \mathrm{O}_{3}\right)$ and calcium oxide $(\mathrm{CaO})$ in ammonia hydroxide $\left(\mathrm{MN}_{4} \mathrm{OH}\right)$ that with application of this intensifying addition the prepared supersphosphate possesses improved physical- chemical and mechanical properties, in this case a mechanical strength reaches $25,2-26,0 \mathrm{MPa}$ and a yield of commodity fraction is $85,8-86,7 \%$.

\section{Acknowledgements}

We thank Prof. E.B.Guseinov, rector of Sumgait State University for valuable advices and consultations, and also we express our deep gratitude D.R.Nurullayeva leading researcher of Institute of Polymer Materials of Azerbaijan National Academy of Sciences, for help in preparing the English version of the paper.

\section{References:}

1. R.Birudaraj, S. Goskonda, P.G. Pande (2010) Granulation Characterization, in: Handbook of Pharmaceutical granulation Technology (Ed., Parikh D.M.), 2010, p. 513-534.

2. L.P.Firsova (2000) Strength of granules on the basis of crystallosulfates of calcium sulfate, Vest. Moscow University. Ser.2. Khimiya. 15( 2000) 331-335.

3. B.Gómez, E.Gordo, E.M. Ruiz-Navas, J.M. Torralba (2006) Influence of the chemical composition and particle size of the metal matrix, on TiCN-reinforced Fe-based composites, Journal of Achievements in Materials and Manufacturing Engineering 17 (1) ( 2006) 57-62.

4. G.I.Kelbaliev, V.M. Samedli, M.M.Samedov (2009) Khim.Prom. Improvement of strength properties of granules with the aim of intensification of granulation process of powdery materials, Today. 7 (2009)4-7 (Russian).

5. G.I.Kelbaliyev, V.M.Samedli, M.M.Samedov (2009) Modelling of granule formation process of powdered materials by the method of rolling, Powder Technology 194 (2009) 87-94.

6. Xin Deng, R.P.Paferson, K.K.Chawla et al. (2002) Journal of Material Science Letters 21 (2002) 707-709.

7. M.V.Tauk, N.V. Gorshkova, T.N. Cherkasova, et al. (2007) Method of preparation of granulated calcium carbonate, Patent Russian, №2005130084/15 on 27.05.2007.

8. G.I.Kelbaliev, V.M.Samedli, M.M.Samedov (2010) Method of preparation of granulated superphosphate, Patent Azerbaijan, I 2010 0022, on 02.04. 2010.

9. E.Ryshkewitch (1953) Journal of the American Ceramic Society 36 (2) (1953) 65- 68.

10. H.Rumpf (1962) The Strength of Granules and Agglomerates, in: W.A. Knepper (ed.): From Agglomeration, Wiley-Interscience, 1962, pp. 379- 418.

11. K.Kendall (1987) Tribology in Particulate Technology. Bristol and Philadelphia: IOP Publishing Ltd., 1987.

12. Ch.N.Satterfield (1976) Mass-transfer in heterogeneous catalysis, Khimiya, Moscow, 1976.

13. G.I.Kelbaliev, M.R.Manafov (2009) Mass transfer in the process of drying of porous materials, Journal of Engineering Physics and Termophysics, Springer, New York 82 (5) ( 2009) 1-8.

14. A.A.Hayaloglu, I.Karabulut ,M.Alpaslan, G. Kelbaliyev (2007) Mathematical modeling of drying characteristics of strained yoghurt in a convective type-dryer, J Food Engineering 78 (2007) 109-117.

15. A.Memmedov, G.I. Kelbaliyev ,G.T. Alisoy, (2010) Solution of an inverse problem for mass transfer in a drying process in a magnetic field, Inverse Problems in Science and Engineering 8 (5) (2010) 723-736.

16. G.I.Kelbaliev, V.M. Samedli, M.M.Samedov, R.K.Kasimova (2010) Evolution of the Distribution Function of Granules in Drum Apparatus,Journal of Applied Chemistry 83 (10) ( 2010) 1692-1697(Russian). 


\begin{tabular}{l|lr|ll|ll} 
& ISRA (India) & $=\mathbf{1 . 3 4 4}$ & SIS (USA) & $=\mathbf{0 . 9 1 2}$ & ICV (Poland) & $=\mathbf{6 . 6 3 0}$ \\
Impact Factor: & ISI (Dubai, UAE) $=\mathbf{0 . 8 2 9}$ & PUH (Russia) $=\mathbf{0 . 2 0 7}$ & PIF (India) & $=\mathbf{1 . 9 4 0}$ \\
& GIF (Australia) & $=\mathbf{0 . 5 6 4}$ & ESJI (KZ) & $=\mathbf{4 . 1 0 2}$ & IBI (India) & $=\mathbf{4 . 2 6 0}$ \\
& JIF & $=\mathbf{1 . 5 0 0}$ & SJIF (Morocco) & $=\mathbf{2 . 0 3 1}$ & & \\
\hline
\end{tabular}

\section{Glossary}

$a-\quad$ size of granules;

$C-\quad$ moisture concentration;

$C_{d}-\quad$ additions concentration;

$D_{*}-\quad$ effective diffusion coefficient;

$D_{0}-\quad$ molecular diffusion coefficient;

$K-\quad$ mass-transfer coefficient;

$P(a, t)-$ distribution function of granules on sizes;

$R-\quad$ radius of granules;

$t-\quad$ time;

$Q-\quad$ yield of the marketable products;

$\varepsilon-\quad$ granules porosity;

$\Delta-\quad$ granules strength;

$\eta_{d}-\quad$ pore tortuosity coefficient of granules;

Fo- $\quad$ Fourier number;

Pe- Peclet number;

Sh- Sherwood number. 